\title{
Vladimir Vasilyevitch Menner
}

The international stratigraphic community and the IUGS family lost one of their most outstanding, respected and admired colleagues when Academician V.V. Menner died on January 6, 1989, at the age of 84 . As Chairman of the IUGS Commission on Stratigraphy in the 1970 s, he did much to reorganize the work of this international body and to spur its members to action. His extensive international experience and his wise counsel served the Union well for many years, and he will be sorely missed by numerous friends and colleagues around the world. The passing of this giant of geology and true gentleman marks the end of an era.

Born in the small town of Shatsk, in the Ryazan region south of Moseow, Vladimir Menner graduated from Moscow State University in 1927. As a student he had already worked on the Kursk Magnetic Anomaly and had taken part in ichthyosaurus excavations near Moseow and expeditions to hunt fossil elephants in the Grozny area of the Caucasus.

Prof. Menner's early scientific research was on the stratigraphy and Tertiary fish fauna of various parts of the Caucasus, Crimea, central Russia and Kazakhstan. From 1930 to 1934 he focused his attention on the detailed stratigraphy and correlation of oil and gas deposits of the Maykop Formation of the eastern Crimea. And from 1936 to 1938 he led an Academy of Sciences expedition to Sochi in search of mineral waters.

During the 1940s, Prof. Menner conducted geological expeditions to the Mesozoic-Cenozoic petroliferous formations of the southern Urals, to almost inaccessible regions of the northeast European part of the U.S.S.R., and to the Polar Urals. Detailed stratigraphic research led to the production of the first tectonic map of the northern Urals. Later (1956-1960), he directed a major geological expedition, sponsored by the Geological Institute of the Academy, to the Kamchatka Peninsula.

From the early 1950s onward, Prof. Menner concentrated on stratigraphy, particularly on stratigraphic classification, correlation of fossiliferous sediments across facies and province boundaries and over great distances, and the development of detailed stratigraphic seales. As he said in his profile published earlier in Episodes (December 1980), "stratigraphic classification and correlation over great distances are particularly important for the Soviet Union, located as it is partly in the Atlantic and Mediterranean regions and partly in the Pacific Ocean belt, thus covering territory underlain by a variety of marine and continental deposits."

A major long-term concern was with problems of periodicity in the development of life, and the relationship of this periodicity with stratigraphy. The unification of stratigraphic scales, then used during the geological mapping of vast reaches of the Soviet Union was another high priority problem. Many academic and industrial geological institutions were faced with this problem, and the U.S.S.R. Interdepartmental Committee for Stratigraphy was organized. One of the most active organizers of this Committee was Vladimir V. Menner, who was from 1955 its Vice-Chairman. With his many contributions, the Committee published numerous recommendations under the titles "Stratigraphic Classification and Terminology" (1956, 1960) and "Stratigraphic Classification, Terminology and Nomenclature" (1965), books that are still widely used by Soviet geologists.

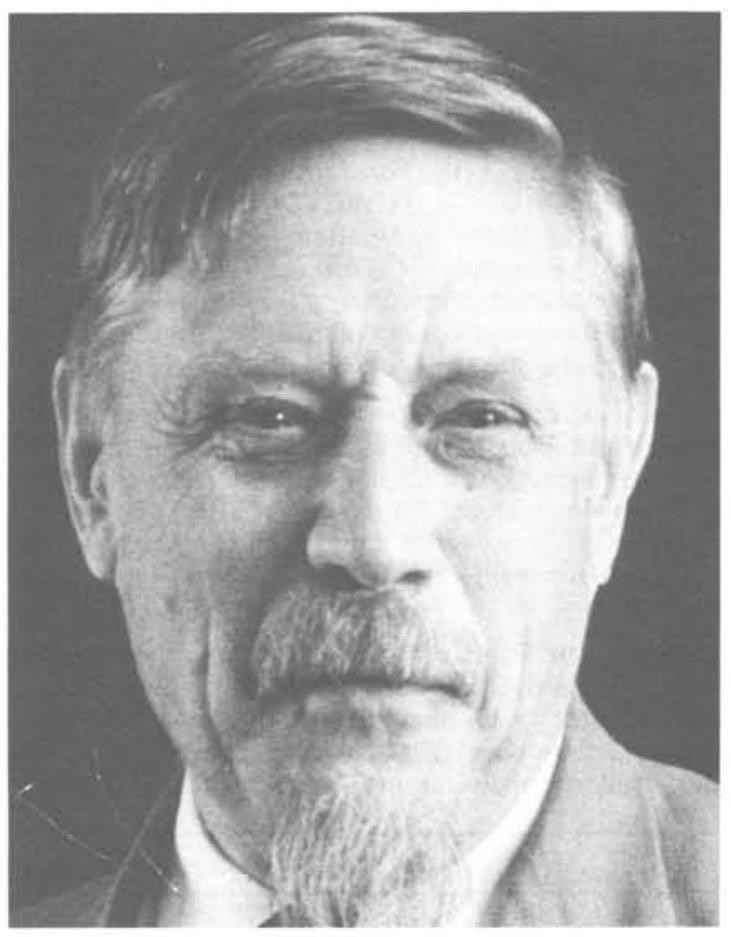

Prof. Menner taught in the Moseow Geological Institute of the Academy of Sciences from 1930 to 1965 . It was here in the late 1950 s that he initiated a new field of research: Precambrian biostratigraphy. He was one of the first to realize the scope for applying biostratigraphic methods to the Precambrian, and his papers on this subject presented at the Copenhagen and New Delhi International Geological Congresses stimulated similar investigations in many countries.

As Head of Stratigraphy in the Geological Institute, Prof. Menner encouraged research on a large range of biostratigraphic correlation methods. These included paleontological-stratigraphic and paleozoological techniques based on studies of classic groups of invertebrates (trilobites, brachiopods, foraminifers etc.) for the Phanerozoic subdivisions, on vertebrate fauna for the Pleistocene and Holocene, and in general on paleobotanic methods based on flora and spore-pollen complexes and others.

Prof. Menner's election in 1960 to the IUGS Subcommission on Stratigraphic Classification and Nomenclature launched a long period of active international work. From 1968 to 1972 he chaired the Commission on Stratigraphy itself, and from 1972 to 1976 he headed the Paleogene Subcommission. He was twice elected Vice-President of IUGS and served from 1976 to 1984 .

Following his election in 1966 as a full member of the Soviet Academy of Sciences, Prof. Menner continued his research on the main task of stratigraphy, the creation of a detailed global stratigraphic seale. As Head of Paleontology in the Faculty of Geology at Moscow State University (1966 on), he published many papers on this and related topics. He was a highly talented teacher who was always surrounded by pupils and followers of several generations. 


\section{In Memoriam}

In 1973 Academician Menner was elected Vice-Chairman and later Chairman of the Soviet National Committee of Geologists - the national adhering member of IUGS, and in 1974 he became Vice-Chairman of the Soviet Committee for IGCP. In his final years he also served as Editor-in-Chief of the geological journal of the U.S.S.R. Academy of Sciences (Izvestia Academii Nauk SSSR, Seria Geologicheskaya), Vice-President of the Paleontological Society of Soviet Union, and as a member of the Scientific Council of the U.S.S.R. Vinistry of Geology. Academician Menner was an Honorary Member of the geological societies of London, France and India; the academies of sciences of Hungary and Yugoslavia; the Royal Society of New Zealand and the Canadian Society of Petroleum Geologists.

In a personal tribute, Dr. Digby McLaren, who succeeded Academician Menner as Chairman of the Commission on Stratigraphy, said "We were associated in many common activities, which included a mutual interest in problems of stratigraphic terminology, biostratigraphy and global correlation. We took part together in the setting up of $I G C P$, and we were both members of the Board during its early years. During his term as President of the Commission on Stratigraphy, he established Sub-commissions and Working Groups for virtually every geological system and the boundaries between them, and turned the Commission into a highly effective international body that engendered a geat deal of research on a global scale. His encouragment and advice were highly valuable in bringing the work of the Silurian-Devonian Boundary Working Group, of which I was Chairman, to a successful conclusion. Menner was immensely influential as a scientist internationally, but he was also, because of his unfailing good humour and warmth of character, an outstanding ambassador for his country. I am proud to have known him and, like many, will miss him sorely."

After a report by R. Volkov, Moscow

\section{RECENT AWARDS}

By the International Association of Engineering Geology, the first Richard Wolters Prize to:

Kiril Anguelov (Institut Supérieur des Mines, Bulgaria) for his work in geotechnique.

By the Geological Society of London to:

A.S. Laughton (retired) the Murchison Medal for his work on sea-bed morphology and his research leadership in the field of ocean floor geology worldwide.

J.M. Hancock (Imperial College London) the Lyell Vedal for his extensive contributions to Cretaceous geology and palaeontology, chalk sedimentation and diagenesis, Cretaceous facies models and for his work as Chairman of the IUGS Subcommission on Cretaceous Stratigraphy.

R.A. Downing (British Geological Survey) the William Smith Medal for his contributions to hydrogeology, especially on groundwater-river flow relationships, on groundwater chemistry and on geothermal resources.

E.H. Francis (University of Leeds) the Major John Sacheverell A'Deane Coke Medal for his major work on British Palaeozoic volcanism and stratigraphy and for his wide-ranging contributions to the geological community.

R.A. Price (Geological Survey of Canada) the Major Edward D'Ewes Fitzgerald Coke Medal for his elucidation of the tectonic evolution of the Southeastern Canadian Cordillera and for his work in teaching and information in the public domain.

T. Elliott (University of Liverpool) the Bigsby Medal for his important research within the field of clastic sedimentology and for fostering links between structural geology and sedimentology.

S.J. Gould (Harvard University) the Sue Tyler Friedman Vedal in recognition of his major contributions to the history of geology and his extensive research into rates and modes of evolution and other aspects of Neo-Darwinism.

By the American Geophysical Union to:

W.H. Munk (Scripps Institution of Oceanography) the William Bowie Medal for outstanding contributions to fundamental geophysics and unselfish cooperation in research.

A.H. Lachenbruch (U.S. Geological Survey) the walter

H. Bucher Medal for original contributions to the basic knowledge of the Earth's crust.
K. Wyrtki (University of Hawaii) the Maurice Ewing Medal for outstanding contributions to marine science. A.G.W. Cameron (Harvard University) the Harry $H$. Hess Medal for outstanding achievements in research into the constitution and evolution of Earth and sister planets.

J.C. Savage (U.S. Geological Survey) the Charles A. Whitten Medal for outstanding achievement in research on the form and dynamics of Earth and planets.

By the U.S. National Academy of Sciences to:

C. Emiliani (University of Miami) the Alexander Agassiz Medal for masterful achievements using isotopic paleotemperatures to establish the climatic history of the Pleistocene and for suggesting their relation to the Milankovitch orbital cycles.

\section{LIST OF ABBREVIATIONS}

AGID Association of Geoscientists for International Development

CCP Commission on Comparative Planetology

CIFEG Centre International pour la Formation et les Echanges Geologiques

CIMP Commission on Metamorphic Petrogenesis

CPCEMR Circum-Pacific Council for Energy and Mineral Resources

CRER Cretaceous Resources Event and Rhythms

IAEG International Association of Engineering Geology

IAGC International Association of Geochemistry and Cosmochemistry

IAGOD International Association on the Genesis of Ore Deposits

IAH International Association of !ydrologists

IAMG International Association for Mathematical Geology

ICL Inter-Union Commission on the Lithosphere

ICS International Commission on Stratigraphy

ICSU International Council of Scientific Unions

IGBP International Geosphere/Biosphere Programme

IGCP International Geological Correlation Programme

ILP International Lithosphere Program

IVA International Mineralogical Association

INHIGEO International Committee on the History of Geological Sciences Cultural Organization 